\title{
Treatment of medical solid waste using an Air Flow controlled incinerator
}

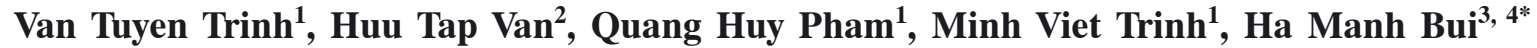 \\ ${ }^{1}$ Vietnam Academy of Science and Technology, Institute of Environmental Technology, No 18, Hoang Quoc Viet road, \\ Ha Noi city, Vietnam \\ ${ }^{2}$ TNU-University of Sciences, Faculty of Natural Resources and Environment, Tan Thinh ward, Thai Nguyen city, Vietnam \\ ${ }^{3}$ Saigon University, Department of Environmental Sciences, 273 An Duong Vuong St., District 5, Ho Chi Minh city \\ 700000, Vietnam \\ ${ }^{4}$ Nguyen Tat Thanh University, NTT Institute of High Technology, 300A Nguyen Tat Thanh Street, District 4, Ho Chi \\ Minh City 700000, Vietnam \\ "Corresponding authors: e-mail: manhhakg@yahoo.com.vn
}

\begin{abstract}
In this study, air flow controlled incinerator (AFCI) was used to treat medical solid waste in Vietnam. The experiment was conducted with solid waste samples that was weighed approximately $2.1-3.3 \mathrm{~kg} / \mathrm{h}$ and had moisture content of 2.8-11.7\%. The results showed that an increase in the airflow rate during the drying process accelerated the combustion time by $10-20 \%$, and the optimal airflow rate was $1.1 \mathrm{~m} / \mathrm{s}$. The combustion time varied from $0-45$ $\min$. The highest temperatures recorded in the drying chamber, carbonisation chamber and combustion chamber after $25-35 \mathrm{~min}$ of operation were varied from $195^{\circ} \mathrm{C}, 775^{\circ} \mathrm{C}$ and $1275^{\circ} \mathrm{C}$, respectively. The temperature of the stack was from $33-68^{\circ} \mathrm{C}$ after the treatment by the wet scrubber using $20 \% \mathrm{NaOH}$ solution. The combustion capacity was $77.3-87.5 \%$. The experimental results revealed the AFCI process advantages including low operation cost and suitability for treating hazardous waste on a small scale.
\end{abstract}

Keywords: Carbonization, hazardous solid waste, incinerator

\section{INTRODUCTION}

Medical solid waste (MSW) is a serious problem around the world. It contains body fluids, gross tissues, and sharps possess pathogens that cause diseases ${ }^{1}$. In 2013, the Ministry of Health found that approximately 17.16 tons of medical waste were released and 16.82 tons of this waste were treated every day in Vietnam (around $95 \%)^{2}$. Inappropriate management of medical waste may produce environmental pollution and negative impact health within a community. Although most medical waste is sorted and treated in medium-sized and large hospitals, sorting in small local healthcare facilities has not been highlighted. In reality, there are two common methods used to eliminate medical waste: landfills and incineration. Landfills are the most common method used for disposing of MSW in developing countries because of the least cost disposal option. However, landfills have greatest negative impact on public and environmental health $^{3}$. Today, medical waste goes through pre-treatment processes, such as sterilisation, autoclaving and microwave processing, before it is sent to landfills which are the final stage in the medical waste disposal process. Therefore, landfills are not the simple method used for medical waste disposal. In contrast, approximately $90 \%$ of hazardous medical waste is treated using the incineration method ${ }^{3,4}$. The incineration of hazardous wastes has many advantages, such as significant volume reduction (approximately 90-95\%), resource recovery ${ }^{5}$, complete destruction of harmful bacteria and non-flammable components. In addition, this method generates high temperatures used in power generation and boilers or industrial furnaces, and incineration does not require much land area when being compared to other methods. Incineration can also be used to decompose hazardous waste, including flammable solvents and infectious hospital waste ${ }^{5,6}$. During the incineration process, hazardous waste is oxidised at high temperatures in an incinerator and converted into gas; non-flammable components are turned into ash and slag. Ash is harmless and can be used in recycled materials. Basic incineration techniques include air-controlled combustion in a furnace or rotary kiln, the fluidised furnace combustion technique, combustion with energy recovery and plasma ${ }^{7-9}$.

Many incinerators with primary and secondary combustion chambers that treat medical wastes have been studied and manufactured ${ }^{\mathbf{1 0}}$. Gas treatment system by absorption combination-wet cyclone ensures the removal of gas components, dust and heavy metals and the regeneration dioxin and furan are prevented by quickly cooling the air to lower than $200^{\circ} \mathrm{C}^{11}$. In general, incinerators that process at high temperatures and gas retention time (GRT) longer than two seconds (in the secondary chamber) may be used to burn domestic and hazardous solid waste. However, most of these incinerators use fossil fuels have to reach the desired temperature in their combustion chambers. In Vietnam, many hospitals set up incineration systems for medical solid waste treatment, but these systems were not efficient due to the high cost of the fossil fuel used in the combustion chambers (approximately $0.5-1.0 \mathrm{USD} / \mathrm{kg})^{2}$. Therefore, a novel incineration technology for hazardous and domestic solid waste that has lower combustion incineration costs must be developed.

In this study, fuel free incineration technology was experimented to evaluate and decide the optimal operating conditions so as to develop a new technique in treating medical solid wastes of hospitals in Ha Noi, Viet Nam. An air flow-controlled incinerator (AFCI) with a capacity of $50 \mathrm{~kg} /$ day was developed and manufactured to replace the fuel incinerators used in the treatment of industrial and medical waste. The AFCI utilized the temperature from the combustion process to dry hazardous waste, so it does not require auxiliary drying equipment. The combustion process is completely controlled by natural 
airflow. The system does not require burners or fuel, so the investment and operating costs are significantly lower than fuel combustion systems. Some experiment conditions were conducted in order to specify the optimal conditions of the incinerator including: effects of medical solid wastes moisture, temperature and airflow rate.

\section{MATERIAL AND METHODS}

\section{Experimental materials}

Medical solid waste (MSW) was collected from Hanoi Hospital in Hanoi, Vietnam. The components and characteristics of the wastes are presented in Table 1. The amount of MSW in Hanoi Hospital was $50 \mathrm{~kg} / \mathrm{day}$. The study was conducted for one year.

Table 1. Hanoi Hospital's MSW components

\begin{tabular}{|l|l|c|}
\hline No & \multicolumn{1}{|c|}{ Component } & Percentage [\%] \\
\hline 1 & $\begin{array}{l}\text { General waste: Paper, organic waste, } \\
\text { metals, metal box, soil and other wastes }\end{array}$ & 77.3 \\
\hline 2 & $\begin{array}{l}\text { Chemical and pharmaceutical waste: } \\
\text { Medicine bottles, medicine bags, } \\
\text { pharmaceutical bottles and bags, blood } \\
\text { bags, medical plastic, glass, syringes, } \\
\text { injection vials, ampoule and waste } \\
\text { sharps }\end{array}$ & 13.3 \\
\hline 3 & $\begin{array}{l}\text { Infectious waste: Tissue and } \\
\text { pathological waste, absorbent cotton } \\
\text { items, gauze, bandages, broken bones } \\
\text { and fixed braces }\end{array}$ & 9.4 \\
\hline
\end{tabular}

The generation of MSW in hospitals depends on many factors, such as hospital location, type of healthcare services and extent of equipping ${ }^{12}$. MSW from a hospital is typically divided into three categories: general waste, chemical and pharmaceutical waste and infectious waste $^{13}$. Table 1 shows the constituent of Hanoi Hospital's MSW. Most of the waste (77.3\% of the processed waste) was general waste, which included paper, organic waste, metals, metal boxes, soil and other solids. Chemical and pharmaceutical waste, which included medicine bottles, medicine bags, pharmaceutical bottles and bags, blood bags, medical plastic, glass, syringes, injection vials, ampoule and waste sharps, represented $13.3 \%$ of the processed waste. Finally, infectious waste, which included tissue and pathological waste, absorbent cotton items, gauze, bandages, broken bones and fixed braces, represented $9.4 \%$ of the processed waste. This MSW must be treated to remove all potential human and environmental risks.

\section{System of Air Flow Controlled Incinerator}

\section{Principles and experimental system}

The air flow-controlled incinerator (Fig. 1) is divided into four main chambers: the waste storage chamber (I), drying chamber (II), carbonisation chamber (III) and combustion chamber (IV). The last chamber has the following dimensions: $120 \mathrm{~mm}$ in diameter and $2000 \mathrm{~mm}$ in height. Air is blown into the chambers using a fan, and the airflow is adjusted using valves $\left(\mathrm{Q}_{1}, \mathrm{Q}_{2}\right.$ and $\left.\mathrm{Q}_{3}\right)$.

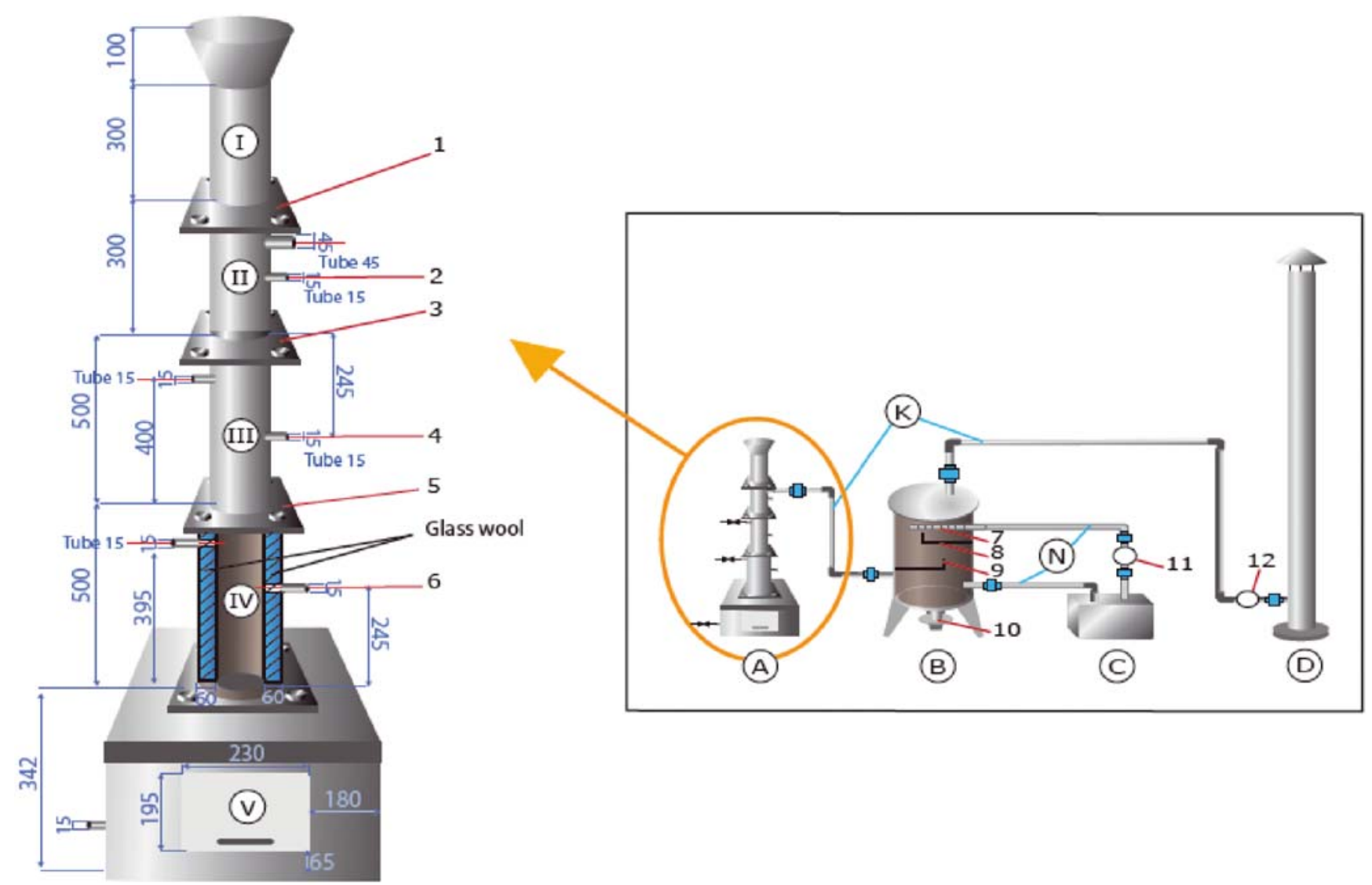

Figure 1. Air flow controlled incinerator (AFCI) with a capacity of $50 \mathrm{~kg} / \mathrm{day}$

Note: I - Waste storage chamber (volume 7,065,000 $\mathrm{mm}^{3}$ ), II - Drying chamber (volume 5,298,750 $\mathrm{mm}^{3}$ ), III - Carbonisation chamber (volume 10,597,500 $\mathrm{mm}^{3}$ ), IV - Combustion chamber (volume 8,654,625 $\mathrm{mm}^{3}$ ), V - Ash chamber (volume 72,367,200 mm³); A - Wet scrubber, B - Absorption solution tank and C - Stack; 1 - Shield, 2 - Hole for moisture measurement, 3, 5 - Sieve, 2, 4, 6 - Hole for temperature measurement, 7 - Spray, 8, 9 - Grid, 10 - Sludge pipe, 11 - Pump, 12 - Exhaust fan; K - Gas pipeline, $\mathrm{N}-$ Water pipeline, size in $\mathrm{mm}$ 
The airflow rate is decreased or increased based on the waste's moisture.

The process begins when wood is placed into the combustion chamber and burned for approximately $10 \mathrm{~min}$ or until the chamber reaches $300-400^{\circ} \mathrm{C}$. Then, the medical waste is moved from the waste storage chamber to the drying chamber. After the waste is dried, it is dropped into the carbonisation and combustion chambers. The Q1, Q2 and Q3 valves are used to adjust the airflow rate and increase the amount of oxygen in the AFCI so the waste dries and burns more rapidly.

Wastes is added to the incinerator through the waste storage chamber, which has a funnel-shaped structure and is separated from the drying chamber by a shield (1) for convenient loading. The temperature in the chamber may reach up to $70^{\circ} \mathrm{C}$. Waste is continuously added to the drying chamber, which has a temperature range from 80 to $125^{\circ} \mathrm{C}$ and a sieve (3) in the bottom of the chamber. The sieve, which is used to hold the waste in the drying chamber to ensure it has enough time to dry before it is dropped into the next process, can be removed or kept in place. After drying, the waste is dropped into the carbonisation chamber in which the temperature varies from 300 to $500^{\circ} \mathrm{C}$. The combustion chamber temperature varies from 800 to $1200^{\circ} \mathrm{C}$ and is separated from the carbonisation chamber by a sieve (5). The combustion chamber is surrounded by a layer of insulating glass cotton and refractory brick that stores the burned materials in the combustion chamber until the combustion process is completed. Then, the ash is dropped into an ash chamber (V). The combustion stove, which has cube structure, is located at the bottom. The interior of this stove is made of refractory bricks and equipped with an operation door so the ash is easily removed. Holes (2, 4 and 6) are used to measure the moisture and temperature in the drying, carbonisation and combustion chambers.

\section{Gas cleaning systems}

Exhaust gases such as $\mathrm{CO}, \mathrm{CO}_{2}$ and $\mathrm{SO}_{\mathrm{x}}$ are released from the drying chamber while dust and temperature are removed in the absorption wet scrubber (VI) using an $\mathrm{NaOH}$ solution before it enters the stack (VIII). The exhaust gases are contacted to the absorption solution using the spray system inside the wet scrubber. The absorption solution is then circulated. A valve is used to discharge the sludge is located under the wet scrubber.

\section{Experimental Condition}

The experimental processes were conducted continuously at a combustion capacity of $1.0-2.5 \mathrm{~kg} / \mathrm{h}(24-60$ $\mathrm{kg} /$ day), waste moisture content of $10-30 \%$ and airflow rate of $0.8-1.1 \mathrm{~m} / \mathrm{s}$ in the tower. The temperatures in the drying, carbonisation and combustion chambers were maintained at $80-200^{\circ} \mathrm{C}, 300-500^{\circ} \mathrm{C}$ and $800-1200^{\circ} \mathrm{C}$, respectively. The temperature variations were controlled using airflow valves. The generated flue gas treatment was conducted in the adsorption cylindrical tower at an absorption solution rate adjustment of $(20 \% \mathrm{NaOH}$ solution)/(flue gas flow of $\alpha=0.1-0.5 \mathrm{~m}^{3} / \mathrm{m}^{3}$ ) (adsorption solution/flue gas flow rate).

\section{Measurements}

The temperature was monitored using a thermometer (DM6801B, Japan), while the airflow rate was identified using a wind speed meter (UT363 UNI-T, Japan). Emission concentration of gas and dust $\left(\mathrm{PM}_{10}\right)$ was determined by Air and waste gas monitor analysis method and fixed potential by electrolysis method ${ }^{14}$. The MSW was weighted using an electronic scale (JWL Jadever, Taiwan). The waste moisture was calculated using Equation 1, while the ash and combustion contents were calculated using Equations 2 and 3, respectively.

$$
\begin{aligned}
& x_{w}=\frac{m_{0}-m_{1}}{m_{0}} \times 100 \% \\
& x_{T}=\frac{m_{T}}{m_{1}} \times 100 \% \\
& x_{c}=100 \%-x_{w}-x_{T}
\end{aligned}
$$

where $m_{0}$ is the initial weight of the waste, $m_{1}$ is the weight of the dried waste, $\mathrm{m}_{\mathrm{T}}$ is the weight of the ash after it was burned, $x_{w}$ is the moisture level, $x_{T}$ is the ash content and $x_{c}$ is the burning content. The weight and contents were measured using $\mathrm{kg}$ and \%, respectively. Each experiment was performed in triplicate and all data are expressed as averages.

\section{RESULTS AND DISCUSSION}

\section{Hanoi Hospital's MSW characteristics}

Fig. 2 shows the Elemental composition of Hanoi Hospital's MSW. Carbon - C made up the largest proportion of elements found in the MSW, followed by oxygen - O, ash, hydrogen $-\mathrm{H}$, nitrogen $-\mathrm{N}$ and sulphur $-\mathrm{S}$. The percentage of $\mathrm{C}, \mathrm{H}$ and $\mathrm{O}$ in Hanoi Hospital's MSW was higher but the $\mathrm{N}$, ash and moisture contents were lower than those of municipal solid waste in China ${ }^{\mathbf{1 5}}$. The moisture and heat value of Hanoi Hospital's chemical solid waste were $25 \%$ and $8598 \mathrm{~kJ} / \mathrm{kg}$, respectively, which indicates that Hanoi Hospital's MSW must be treated differently during incineration. The high percentage of moisture in MSW may be due to blood, wet cotton and liquid from infusion bottles and other wet materials.

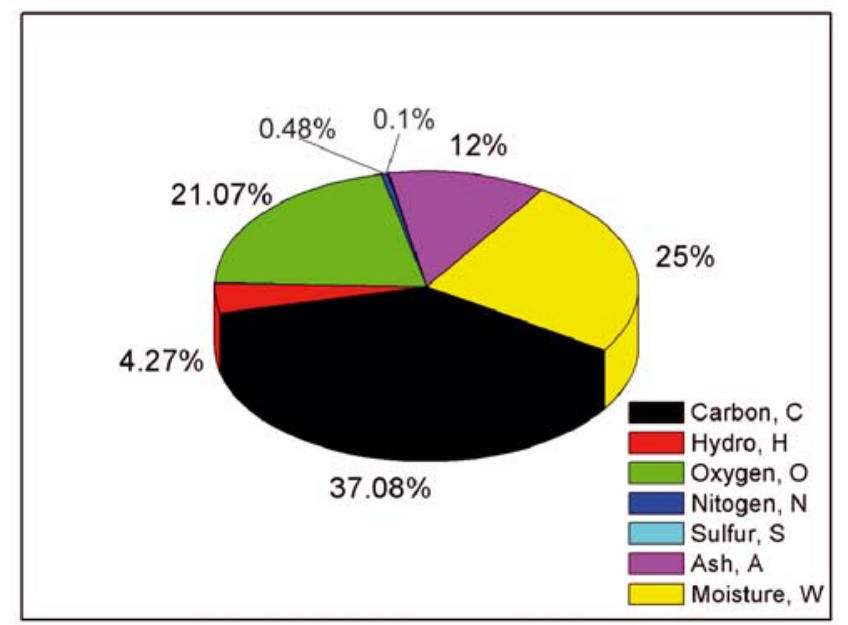

Figure 2. Elemental composition of Hanoi Hospital's solid waste 


\section{Effect of moisture on the AFCI combustion process}

Experiments were conducted using 10 medical waste (MSW) samples that weighed 2-3 kg/sample (Fig. 3). The MSW was burnt directly using the combustion system. The moisture and dried waste samples were burnt at the same time to compare the effect of moisture on combustion time. The chambers in the furnaces reached the optimal operation temperature before the experiment was conducted. To hold the optimal temperature in the furnaces, control of the airflow to the chambers using the temperature values was necessary ${ }^{\mathbf{1 6}}$. The weight, moisture and incineration time of the dried MSW samples in the inlet and outlet chambers are shown in Fig. 3, where $T_{1}$ is the combustion time of the raw MSW and $\mathrm{T}_{2}$ is the
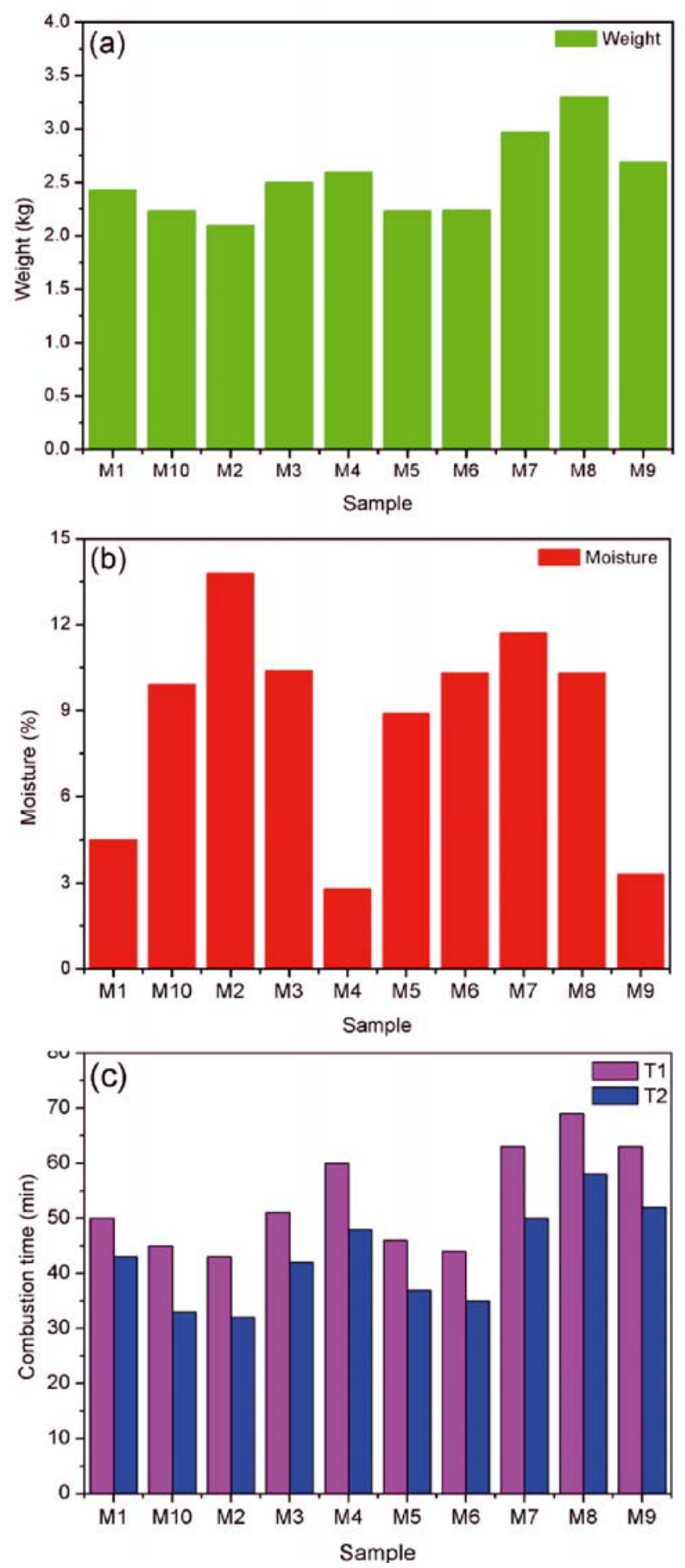

combustion time of the dried MSW. Fig. 3a and c show that the longest combustion times were 63-69 $\min \left(\mathrm{T}_{1}\right)$ and 50-58 $\min \left(\mathrm{T}_{2}\right)$ for M7 and $\mathrm{M} 8$, respectively. These results may be due to the higher moisture levels in the M7 and M8 samples. However, M2 was an exception as it had the highest moisture level $(13.8 \%)$, but it was incinerated faster than M7, M8 and M9, possibly because M2 was the smallest sample $(2.1 \mathrm{~kg})$. The experimental results support previous studies in which combustion time increased when the MSW has a higher moisture level and decreases when the weight of the MSW is lower ${ }^{17}$.

Fig. 3 also shows a significant difference in the combustion time between raw MSW (with moisture) and dried MSW. Raw MSW took longer to burn due to the
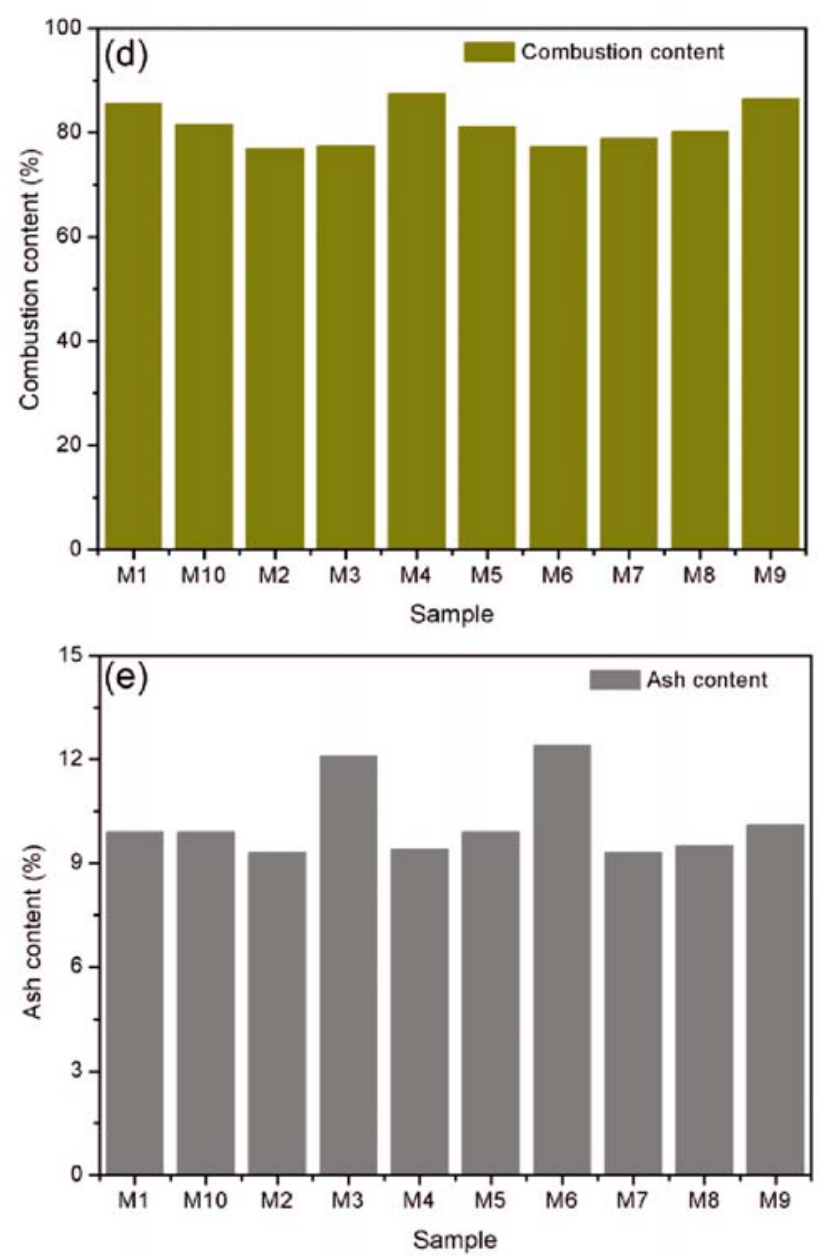

Figure 3. Parameters and combustion time of wastes in the AFCI, M1-M10 from random Hanoi Hospital MSW samples used in 10 experiments 
time it took to remove the moisture in the drying and carbonisation chambers before it entered the combustion chamber. The combustion content calculation showed that the MSW treatment capacity in the AFCI was relatively stable; the combustion content maintained at more than $75 \%$. However, Fig. 3 illustrates that the combustion results depended on the MSW drying capacity based on the differences in the MSW moisture levels, which may be mitigated by optimising the drying and carbonisation processes through adjustments in the airflow rate during combustion.

\section{Effect of temperature on the combustion process in AFCI}

In the experiments, $2 \mathrm{~kg}$ of MSW samples (M1-M10 in Fig. 3) were burned using AFCI. The temperature of the chambers was evaluated every 5 min during the burning processes. The combustion process time was up to $45 \mathrm{~min}$. The temperatures of each chamber for all the combustion times are presented in Fig. 4, which also shows that the chambers reached the desired temperature 15 min after the start of the combustion processes. The maximum drying, and carbonisation temperature were $195^{\circ} \mathrm{C}$ and $755^{\circ} \mathrm{C}$, respectively, after $35 \mathrm{~min}$ of burning, while combustion chamber temperatures reached $1275^{\circ} \mathrm{C}$ after 25 min. Yang et al. (2007) ${ }^{7}$ stated that the MSW burning temperature in the AFCI combustion chamber was similar to a general fuel incinerator. In this study, the temperature increased from the drying chamber to the carbonisation and combustion chambers due to the heat value released after each process. The temperature source started in the combustion chamber, which led to an increase in the temperature within the carbonisation chamber, creating syngas and burning, which increased the temperature in the drying chamber. However, the time

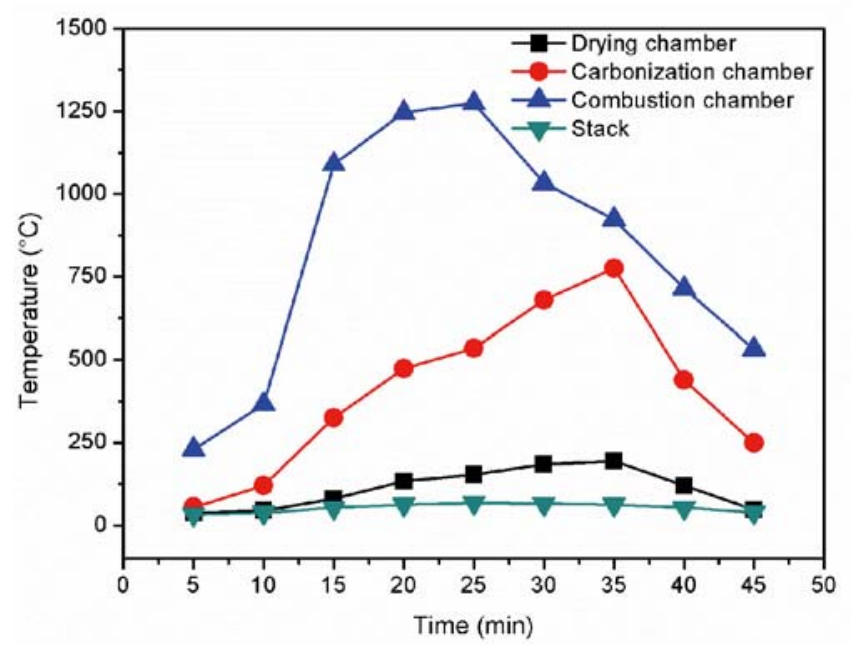

Figure 4. The temperatures in the functional chambers during the combustion process

Table 2. Averaged observed values of flue gas from AFCI it took to reach the desired temperature in the drying chamber depended on the amount of inlet airflow due to the natural air from the atmosphere, which suggests that the drying and carbonisation processes may be more effective if the waste is continuously fed into the furnace as the temperatures in these chambers seemed more stable. Moreover, the flue gas contained sulphur oxide, hydrogen chloride, carbon dioxide, etc., which were absorbed using a $20 \% \mathrm{NaOH}$ solution before the gas was released into the stack. The control absorption solution tank not only reduced gas pollution, but also maintained the gas temperature at $33-68^{\circ} \mathrm{C}$ (see Fig. 1). This control method may be found in many studies ${ }^{\mathbf{1 1}, 18}$ that research hazardous waste treatments.

\section{Effect of the airflow rate on combustion time}

The M1-M10 samples were also tested at two different airflow rates $(1.1 \mathrm{~m} / \mathrm{s}$ and $0.8 \mathrm{~m} / \mathrm{s})$ to compare the effect of this factor on combustion time (Fig. 5). Based on the principle of air convection operation in the furnace, the higher the airflow rate, the lower the MSW combustion time. In this study, the combustion time increased from 9 to $17 \mathrm{~min}$ as the airflow rate decreased from $1.1 \mathrm{~m} / \mathrm{s}$ to $0.8 \mathrm{~m} / \mathrm{s}$, and the MSW burnt more quickly at the airflow rate of $1.1 \mathrm{~m} / \mathrm{s}$ than $0.8 \mathrm{~m} / \mathrm{s}$. However, accelerating the suction rate should also be tested to optimise the storage time of the exhaust gas in the furnace and prevent the formation of dioxins and furans.

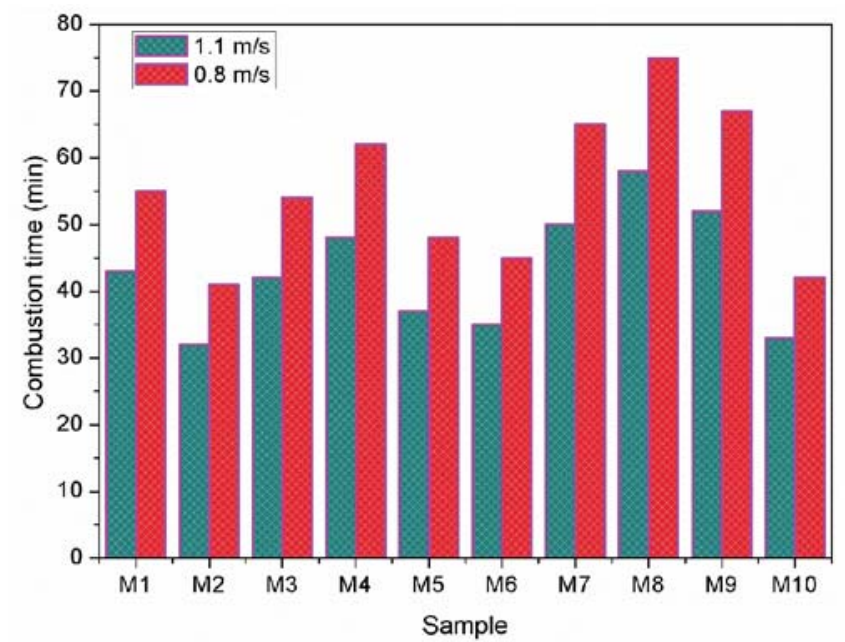

Figure 5. The MSW samples' combustion time at different airflow rates, M1-M10 are random samples of Hanoi Hospital's MSW that were used in 10 experiments

\section{Characteristic of Flue gases releasing during AFCI process}

Most of toxic gases generated from the incineration process such as $\mathrm{CO}_{\mathrm{x}}, \mathrm{SO}_{\mathrm{x}}, \mathrm{HCl}$, etc. were absorbed by $\mathrm{NaOH} 20 \%$ (wt./v.) and after absorbing, the gases met Vietnam's gas effluent standard (QCVN 30:2012/ BTNMT) as seen in Table 2. These results confirmed

\begin{tabular}{|c|c|c|c|c|}
\hline \multirow{2}{*}{ No } & \multirow{2}{*}{ Gas } & Concentration [mg/Nm $\left.{ }^{3}\right]$ & After the stack \\
\cline { 3 - 5 } & & Before wet scrubber & 0.065 & \\
\hline 1 & $\mathrm{CO}$ & 540 & 0.099 & 250 \\
\hline 2 & $\mathrm{CO}_{2}$ & 122 & 0.536 & - \\
\hline 3 & $\mathrm{SO}_{2}$ & 96.52 & 0.00062 & - \\
\hline 4 & $\mathrm{HF}$ & 0.186 & 0.0014 & 50 \\
\hline 5 & $\mathrm{HCl}$ & 0.538 & 0.0125 & 100 \\
\hline 6 & $\mathrm{PM}_{10}$ & 185 & 0.0017 & \\
\hline 7 & Dioxins & 4.58 & & - \\
\hline
\end{tabular}


with the study of Han et al., (2018) ${ }^{\mathbf{1 4}}$ where in using $\mathrm{NaOH}$ for absorbing flue gases from the combustion of $50 \mathrm{~kg}$ solid waste.

\section{CONCLUSIONS}

This study has found that a continuous loading of 50 $\mathrm{kg} /$ day of MSW may be incinerated with the highest temperature (drying chamber: $70-200^{\circ} \mathrm{C}$, carbonisation chamber $300-500^{\circ} \mathrm{C}$ and combustion chamber: $800-$ $1200^{\circ} \mathrm{C}$ ) during $25-35 \mathrm{~min}$ a using an AFCI. The air supply may lead to an increase in treatment efficiency. For example, when the airflow rate was increased from $0.8 \mathrm{~m} / \mathrm{s}$ to $1.1 \mathrm{~m} / \mathrm{s}$, the combustion time was reduced by 10-15 min. Therefore, the combustion process may be controlled using valves that control the airflow rate in each chamber of the AFCI. The combustion time of the dried MSW was 10-15 min less when it was controlled by the drying chamber II valve. These findings suggest the potential of AFCI use in MSW treatment.

\section{ACKNOWLEDGMENT}

This research is funded by Vietnam Academy of Science and Technology under grant number VAST 07.01/17-18.

\section{LITERATURE CITED}

1. Jang, Y.C., Lee, C., Yoon, O.S. \& Kim, H. (2006). Medical waste management in Korea. J. Environ. Manage. 80(2), 107-115. DOI: 10.1016/j.jenvman.2005.08.018.

2. Nguyen, D.L., Bui, X.T. \& Nguyen, T.H. (2014). Estimation of current and future generation of medical solid wastes in Hanoi City, Vietnam. Int. J. Waste Resour. 4(2), 1-5. DOI: 10.4172/2252-5211.1000139.

3. Koolivand, A., Mazandaranizadeh, H., Binavapoor, M., Mohammadtaheri, A. \& Saeedi, R. (2017). Hazardous and industrial waste composition and associated management activities in Caspian industrial park, Iran. Environ. Nanotechnol. Monit. Manage. 7(5), 9-14. DOI: 10.1016/j.enmm.2016.12.001.

4. Shen, H.M., Chyang, C.S., Lin, K.P. \& Chen, M.F. (2019). Fluidized bed incinerator for medical waste that generates no residual dioxin: a mini-review. J. Chin. Inst. Eng. 42(5), 438-448. DOI: 10.1080/02533839.2019.1598289.

5. Li, M., Xiang, J., Hu, S., Sun, L.S., Su, S., Li, P.S. \& Sun, X.X. (2004). Characterization of solid residues from municipal solid waste incinerator. Fuel. 83(10), 1397-1405. DOI: 10.1016/j. fuel.2004.01.005.

6. Zhu, H.M., Yan, J.H., Jiang, X.G., Lai, Y.E. \& Cen, K.F. (2008). Study on pyrolysis of typical medical waste materials by using TG-FTIR analysis. J. Hazard. Mater. 153(2), 670-676. DOI: 10.1016/j.jhazmat.2007.09.011.

7. Yang, Y., Pijnenborg, M.J.A., Reuter, M.A. \& Verwoerd, J. (2007). Analysis of transport phenomena in a rotary-kiln hazardous waste incinerator. Prog. Comput. Fluid. Dy. 7(1), 25-39. DOI: 10.1504/PCFD.2007.011883.

8. Leckner, B. (2015). Process aspects in combustion and gasification Waste-to-Energy (WtE) units. Waste Manage. 37(3), 13-25. DOI: 10.1016/j.wasman.2014.04.019.

9. Pham, T.H., Bui, H.M. \& Khacef, A. (2018). Oxidation of propene from air by atmospheric plasma-catalytic hybrid system. J. Serb. Chem. Soc. 83(5), 641-649. DOI: 10.2298/ JSC171014012P.

10. Li, W., Ma, Z., Huang, Q. \& Jiang, X. (2018). Distribution and leaching characteristics of heavy metals in a hazardous waste incinerator. Fuel. 233(12), 427-441. DOI: 10.1016/j. fuel.2018.06.041.
11. Chang, M.B., Lin, J.J. \& Chang, S.H. (2002). Characterization of dioxin emissions from two municipal solid waste incinerators in Taiwan. Atmos. Environ. 36(2), 279-286. DOI: 10.1016/S1352-2310(01)00267-9.

12. Yuwono, A.S. \& Ersa, N.S. (2018). Evaluation of Medical Solid Waste Management: A Case Study of Two Hospitals in Bogor, Indonesia. Int. J. Appl. Environ. Sci. 13(3), 323-337.

13. Jaafari, J., Dehghani, M.H., Hoseini, M. \& Safari, G.H. (2015). Investigation of hospital solid waste management in Iran. World Rev. Sci. Technol. Sustainable Dev. 12(2), 111-125. DOI: 10.1504/WRSTSD.2015.073820.

14. Han, J.H., You, F., Li, P., Dong, Q., Qin, S.H. \& Fan, D.D. (2018). Properties and Reliability Evaluation of Consecutive Pyrolysis and Incineration Disposal Process for FR-4 Waste Printed Circuit Boards. Procedia Eng. 211, 205-214. DOI: 10.1016/j.proeng.2017.12.006.

15. Chen, D. \& Christensen, T.H. (2010). Life-cycle assessment (EASEWASTE) of two municipal solid waste incineration technologies in China. Waste Manage. Res. 28(6), 508-519. DOI: $10.1177 / 0734242 X 10361761$.

16. Dvořák, R., Pařízek, T., Bébar, L. \& Stehlík, P. (2009). Incineration and gasification technologies completed with up-to-date off-gas cleaning system for meeting environmental limits. Clean Technol. Environ. Policy 11(1), 95-105. DOI: 10.1007/s10098-008-0170-7.

17. Manyele, S.V. \& Kagonji, I.S. (2012). Analysis of medical waste incinerator performance based on fuel consumption and cycle times. Eng. 4(10), 625-635. DOI: 10.4236/eng.2012.410080.

18. Ahmad, T., Park, J., Keel, S., Yun, J., Lee, U., Kim, Y. \& Lee, S.S. (2018). Behavior of heavy metals in air pollution control devices of $2,400 \mathrm{~kg} / \mathrm{h}$ municipal solid waste incinerator. Korean J. Chem. Eng. 35(9), 1823-1828. DOI: 10.1007/ s11814-018-0101-1. 